\title{
ASSESSMENT OF AFFILIATED SOCIAL ATTITUDES BASED ON PEER AND SELF ASSESSMENT TECHNIQUES IN CURRICULUM 2013 FOR ELEMENTARY SCHOOL PARTICIPANTS
}

\section{Dessy Nur Maulina, St. Y. Slamet, Mintasih Indriayu}

Universitas Sebelas Maret

desaynurm@gmail.com

Article History

accepted 09/07/2018

approved 01/08/2018

published 17/09/2018

\section{Keywords}

penilaian afektif, peer and self assessment

\begin{abstract}
Penilaian merupakan salah satu komponen pokok dalam proses pembelajaran. Penilaian atau asesmen seharusnya dilakukan sebagai upaya untuk mengukur tingkat ketercapaian indikator pembelajaran. Tujuan dari penelitian ini adalah untuk menjelaskan penilaian afektif sikap sosial berbasis teknik peer and self assessment pada kurikulum 2013. Metode yang digunakan dengan menggunakan metode diskriptif kualitatif. Pengumpulan data dengan menggunakan studi pustaka. Hasil pembahasan dari penulisan ini menyimpulkan bahwa kemampuan afektif merupakan bagian dari hasil belajar yang memiliki peran sangat penting. Model penilaian afektif berbasis teknik peer and self assessment merupakan model penilaian inovatif yang sedang dikembangkan di dunia pendidikan karena model penilaian ini dapat memberikan dampak positif pada perkembangan kepribadian peserta didik.
\end{abstract}

Social, Humanities, and Education Studies (SHEs): Conference Series https://jurnal.uns.ac.id/shes
p-ISSN 2620-9284 e-ISSN 2620-9292 


\section{PENDAHULUAN}

Menteri Pendidikan dan Kebudayaan dalam kebijakannya menjelaskan bahwa pada Kurikulum 2013 diharapkan dapat menghasilkan insan Indonesia yang produktif, kreatif, inovatif, efektif melalui penguatan penilaian sikap, keterampilan dan pengetahuan yang terintegrasi (Kemendikbud, 2013a: 1). Berdasarkan hal tersebut pembelajaran seyogyanya dapat mewadahi semua aspek baik dari pengetahuan, sikap, dan keterampilan. Dengan demikian, maka diinterpretasikan bahwa sistem penilaian pada Kurikulum 2013 menjadi semakin komplek.

Penilaian yang berupa tes tersebut belum bisa untuk mengetahui gambaran yang utuh mengenai penilaian pengetahuan, sikap dan keterampilan siswa yang dikaitkan dengan kehidupan nyata mereka baik di luar sekolah atau masyarakat. Sesuai dengan pendapat Mendler (dalam Catherine 2013: 2) menjelaskan bahwa:

"Educator shold adopt change in the field of teaching by applying varieties of teaching methodologies and strategies that will guide in planning a smooth operation and management of all element contributory to student learning and to improve the quality of education". Yang artinya bahwa "Pendidikan berani mengadopsi perubahan di bidang pengajaran dengan menerapkan berbagai metodologi pengajaran dan strategi yang akan membimbing dalam kelancaran perencanaan dan pengelolaan semua elemen yang berkontribusi terhadap pembelajaran siswa dan untuk meningkatkan kualitas pendidikan".

Penilaian merupakan salah satu komponen pokok dalam proses pembelajaran. Penilaian bertujuan untuk mengetahui tingkat ketercapain tujuan pembelajaran dan melihat keefektifan proses belajar mengajar (Wijayanti, 2014). Penilaian atau asesmen seharusnya dilakukan sebagai upaya untuk mengukur tingkat ketercapaian indikator pembelajaran dan mengumpulkan informasi perkembangan belajar siswa pada berbagai aspek, aspek yang diukur meliputi aspek kognitif, psikomotorik, dan afektif yang diwujudkan dengan adanya perubahan cara berfikir siswa, baik secara individu maupun kelompok (Astuti et al., 2012). Penilaian yang dianjurkan oleh kurikulum adalah penilaian yang tidak hanya terfokus pada penilaian aspek kognitif, tetapi juga mencakup aspek afektif dan aspek psikomotorik (Dewi et al., 2013). Proses penilaian harus dapat mengukur hasil belajar siswa baik dari aspek kognitif, afektif, maupun psikomotorik (Irsyad \& Sukaesih, 2015). Penilaian yang dapat mengukur semua aspek tersebut salah satunya adalah penilaian autentik (Nurjananto \& Kusumo, 2015).

Teknik penilaian diri ( self assessment) dan penilaian teman sejawat ( peer assessment ) adalah salah satu teknik dalam penilaian autentik yang dapat digunakan untuk mengukur sikap siswa (Majid, 2014). Penilaian diri atau self assessment dipilih sebagai salah satu teknik dalam melakukan penilaian sikap dikarenakan teknik ini terbukti efektif dalam mempengaruhi sikap positif siswa di dalam pembelajaran (Basnet, 2011). Penerapan self assessment pada siswa bertujuan untuk memberikan umpan balik kepada siswa agar siswa dapat memperbaiki sikap dan cara belajarnya (Ardiana \& Sudarmin, 2015). ), pendapat lain disampaikan oleh Cheung (2011), yang menjelaskan bahwa dengan teknik penilaian self dan peer assessment siswa dapat merefleksikan diri mereka dan rekan-rekan mereka sehingga diharapkan mereka dapat merefleksikan sikap mereka dan meningkatkan sikap mereka ke arah yang positif.

Berdasarkan kenyataan di lapangan terdapat beberapa permasalahan yaitu proses kegiatan pembelajaran masih berpusat pada guru (student center), kurangnya penerapan model pembelajaran pada saat proses kegiatan pembelajaran, penggunaan bahan ajar yang hanya terfokus pada satu bahan ajar, proses penilaian masih berorientasi pada penilaian kognitif/ pengetahuan, walaupun dalam membuat laporan penilaian sudah mencakup $\mathrm{KI}-2, \mathrm{KI}-3$ dan $\mathrm{KI}-4$ tetapi dalam penerapan pada penilaian Kurikulum 2013 masih menggunakan penilaian kurikulum 2006. 
Permasalahan guru yang melaksanakan penilaian yang berorientasi pada penilaian kognitif dikarenakan guru yang belum bisa membuat penilaian afektif khususnya penilaian sikap. Banyak hal yang menjadi kebingungan, diantaranya mulai dari apa yang akan dinilai yaitu sikap sosialnya, membuat rubrik penilaian, sampai merekap nilai akhir. Kesulitan yang dihadapi oleh guru bukan mereka tidak mendapatkan pelatihan dan sosialisasi penilaian, melainkan memang mereka sulit untuk menerapkan dalam proses kegiatan pembelajaran. Selain mereka harus menjelaskan materi pembelajaran, tetapi mereka juga harus fokus dalam menilai sikap yang akan diamati secara langsung.

Maka dari itu penilaian sikap sosial berbasis teknik peer and self assessmen sangat diperlukan untuk mengukur sikap siswa. Penilaian sikap sosial dengan teknik peer and self assessment dapat meringankan dan membantu guru dalam menganalisis dan merekap data yang telah didapat dari observasi selama proses pembelajaran, sehingga penilaian sikap sosial dapat terlaksana dengan baik sesuai dengan yang diharapkan. Dengan demikian, agar berkesinambungan antara penilaian dan kegiatan proses pembelajaran, diperlukan instrumen penilaian yang berisikan rubrik penilaian. Dari rubrik penilaian inilah guru dapat menilai sikap siswa melalui observasi atau pengamatan langsung, setelah itu guru dapat menganalisis melalui tabel ceklis dan selanjutnya dengan perekapan data hasil ceklis yang diperoleh.

\section{METODE}

Metode yang digunakan dengan menggunakan metode diskriptif kualitatif. Metode pengumpulan data dengan menggunakan studi pustaka.

\section{Kurikulum 2013}

\section{PEMBAHASAN}

Kurikulum 2013 merupakan kurikulum yang baru ini menjadi perbincangan banyak orang, karena kurikulum ini mulai di terapkan pada tahun pelajaran 2013. Kurikulum ini merupakan pengembangan dari kurikulum yang telah ada sebelumnya, yaitu Kurikulum Tingkat Satuan Pendidikan (KTSP). Perubahan Kurikulum 2013 sesuai dengan Permendikbud Nomor 22 Tahun 2016 tentang Standar Proses Penilaian Dasar dan Menengah berisi tentang kriteria mengenai pelaksanaan pembelajaran pada satuan pendidikan dan menengah untuk mencapai kompetensi lulusan.

Adanya Kurikulum 2013 diharapkan mampu membuat peserta didik dapat memiliki kompetensi sikap, pengetahuan dan keterampilan yang dapat meningkat dan berkembang sesuai dengan jenjang pendidikan yang telah ditempuh. Dengan begitu akan dapat menentukan dan berpengaruh pada kesuksesan dalam kehidupan selanjutnya. Kurikulum 2013 diharapkan mampu memberikan keseimbangan penilaian pada aspek afektif, kognitif dan psikomotor secara berimbang, sehingga pembelajaran yang terjadi diharapkan dapat berjalan dengan menyeimbangkan ketiga aspek tersebut.

Kemampuan afektif merupakan bagian dari hasil belajar yang memiliki peran yang sangat penting. Keberhasilan pada ranah kognitif dan psikomotorik sangat ditentukan oleh kondisi afektif peserta didik. Peserta didik yang memiliki minat belajar dan sikap positif terhadap pelajaran akan merasa senang mempelajari mata pelajaran tertentu, sehingga dapat mencapai hasil pembelajaran yang optimal. Walaupun para pendidik sadar akan hal ini, namun belum banyak tindakan yang dilakukan pendidik secara sistematik untuk meningkatkan minat peserta didik. Pencapaian hasil belajar yang optimal, dalam mencapai program pembelajaran dan kegiatan pembelajaran bagi peserta didik, pendidik harus memperhatikan karakteristik afektif peserta didik (Depdiknas, 2008:2). 


\section{Penilaian Afektif Sikap Sosial}

Menurut Permendikbud No. 23 Tahun 2016 Bab I tentang Standar Penilaian Pendidikan menjelaskan bahwa penilaian adalah proses pengumpulan dan pengolahan informasi untuk mengukur pencapaian hasil belajar peserta didik. Sesuai dengan pendapat menurut Gronlund dan Linn dalam Kusaeri dan Suprananto (2012:8) menjelaskan bahwa:

"Penilaian sebagai suatu proses yang sistematis dan mencakup kegiatan mengumpulkan, menganalisis serta menginterpretasikan informasi untuk menentukan seberapa jauh seorang peserta didik atau sekelompok peserta didik mencapai tujuan pembelajaran yang telah ditetapkan, baik aspek pengetahuan, sikap dan keterampilan".

Permendikbud Nomor 23 Tahun 2016 tentang Standar Penilaian Pendidikan Bab III Pasal 4 menjelaskan bahwa:

"Tujuan penilaian diantaranya (1) Penilaian hasil belajar oleh pendidik bertujuan untuk memantau dan mengevaluasi proses, kemajuan belajar, dan perbaikan hasil belajar peserta didik secara berkesinambungan; (2) Penilaian hasil belajar oleh satuan pendidikan bertujuan untuk menilai pencapaian Standar Kompetensi Lulusan untuk semua mata pelajaran; (3) Penilaian hasil belajar oleh Pemerintah bertujuan untuk menilai pencapaian kompetensi lulusan secara nasional pada mata pelajaran tertentu.

Menurut Subali (2010: 35) menjelaskan bahwa manfaat dari penilaian adalah untuk melaksanakan bimbingan belajar, bimbingan pribadi dan kebutuhan subjek belajar yang berkaitan dengan pembelajarannya. Penilaian autentik yang telah diterapkan pada Kurikulum 2013 memiliki tujuan sebagai upaya untuk mengetahui kemampuan dan hasil belajar peserta didik, selain tujuan, penilaian juga memiliki sasaran penilaian. Penilaian merupakan serangkaian kegiatan yang dilakukan secara sistematis dan berkesinambungan untuk memperoleh data/ informasi tentang proses dan hasil belajar peserta didik. Pelaksanaan penilaian harus dilakukan secara menyeluruh kepada peserta didik, baik dari segi pemahamannya terhadap materi atau bahan pelajaran yang telah diberikan (aspek kognitif/ pengetahuan), maupun dari segi penghayatan (aspek afektif/ sikap), dan pengalamannya (aspek psikomotor/ keterampilan).

Menurut Popham (dalam Sukanti, 2011: 74) menjelaskan bahwa ranah afektif menentukan keberhasilan seseorang. Maksudnya adalah orang yang tidak memiliki kemampuan afektif yang baik maka akan sulit mencapai keberhasilan yang optimal. Keberhasilan ini maksudnya keberhasilan pada ranah afektif, kognitif dan psikomotor sangat ditentukan oleh kondisi peserta didik yang afektif juga. Menurut Hamzah, dkk. (2016: 29) menjelaskan bahwa sikap mucul dari perasaan (suka maupun tidak suka) yang terkait dengan kecenderungan bertindak seseorang dalam menanggapi atau merespon sesuatu/ objek. Pada umumnya sebagian guru lebih banyak menekankan pembelajaran kognitif/ pengetahuan dalam pembelajaran, sehingga orientasi berpikir dan belajar peserta didik hanya pada pengetahuannya saja.

Menurut Muslikh (2016: 4) menjelaskan bahwa berdasarkan buku panduan penilaian sikap Kurikulum 2013 memiliki karakteristik sebagai berikut: (1) Belajar Tuntas merupakan pencapaian minimal dari kompetensi setiap muatan pelajaran yang seharusnya dikuasai oleh peserta didik dalam kurun waktu tertentu; (2) Penilaian dilakukan untuk mengukur pencapaian kompetensi secara holistik. Berarti menilai secara bersama dari aspek sikap, pengetahuan dan keterampilan sesuai dengan kondisi yang sebenarnya/ nyata; (3) Berkesinambungan sebagai penilaian yang dilakukan secara terus menerus dan berkelanjutan selama pembelajaran berlangsung. Tujuannya yaitu untuk mendapatkan gambaran secara utuh mengenai gambaran hasil belajar peserta didik, memantau proses pembelajaran, kemajuan pembelajaran dan 
perbaikan hasil secara terus menerus dengan menggunakan berbagai macam teknik penilaian; (4) Menggunakan bentuk dan teknik penilaian yang bervariasi dimaksudkan bahwa penilaian sikap, pengetahuan dan keterampilan dapat menggunakan berbagai teknik penilaian yang sesuai dengan karakteristik kompetensi yang akan di ukur dan dinilai; (5) Berdasarkan acuan kriteria dimaksudkan agar pada penilaian sikap, pengetahuan dan keterampilan menggunakan acuan kriteria. Kemampuan peserta didik tidak dapat dibandingkan dengan kelompok, melainkan dapat dibandingkan terhadap ketuntasan yang ditetapkan.

Adapun teknik penilaian sikap sesuai dengan Permendikbud Nomor 66 Tahun 2013 tentang Standar Penilaian, menjelaskan bahwa teknik penilaian sikap antara lain: (1) Observasi adalah penilaian yang dilakukan secara berkesinambungan dengan menggunakan indra baik secara langsung maupun tidak langsung; (2) Penilaian diri adalah penilaian diri yang dilakukan dengan cara meminta peserta didik untuk mengemukakan kelebihan dan kekurangan dirinya; (3) Penilaian antar teman adalah penilaian dengan meminta peserta didik untuk saling menilai terkait dengan pencapaian kompetensi; (4) Jurnal adalah catatan peendidik di dalam dan di luar kelas yang berisi informasi hasil pengamatan tentang kekuatan dan kelemahan peserta didik terkait dengan sikap dan perilaku.

Menurut Permendikbud Nomor 21 Tahun 2016 Bab II tentang Tingkat Kompetensi menjelaskan bahwa sikap sosial menunjukkan perilaku jujur, disiplin, santun, percaya diri, peduli dan tanggungjawab dalam beronteraksi dengan keluarga, teman, guru dan tetangga dan negara.

Menurut Basuki (2015: 196) menjelaskan bahwa terdapat 11 (sebelas) langkah dalam pengembangan instrumen penilaian sikap, antara lain: Menentukan spesifikasi instrumen, Menulis instrumen, Menentukan skala instrumen, Menentukan pedoman pemberian skor, Menelaahan instrumen, Merakit instrumen, Melaksanakan uji coba, Menganalisis hasil uji coba, Memperbaiki instrumen, Melaksanakan pengukuran, Menafsirkan hasil pengukuran.

\section{Teknik peer and self assessment}

Kompleksitas model pembelajaran yang diterapkan seyogyanya diikuti dengan pengguanaan penilaian yang kompleks, sehingga semua aspek siswa dapat diukur, dan penilaian autentik dapat digunakan sebagai alternatif dalam melakukan penilaian Kurikulum 2013 diharapkan mampu menerapkan semua aspek dari penilaian Kurikulum 2013. Selain mampu menerapkan model pembelajaran tetapi juga mampu menerapkan penilaian yang secara kompleks. Dengan menerapkan penilaian ini dapat menilai semua aspek penilaian agar peserta didik dapat di ukur dan penilaian autentik dapat digunakan sebagai alternatif dalam melakukan penilaian. Menurut Chaney dan Ingraham (dalam Evelyn, 2016: 21) menjelaskan bahwa peer assessment merupakan metode yang efektif untuk meningkatkan kualitas belajar peserta didik. Sejalan dengan pendapat menurut Astuti et al. (2012) menjelaskan bahwa jenis penilaian yang dapat dikembangkan antara lain peer and self assessment.

Peer assessment merupakan penilaian yang dilakukan oleh teman sejawat/ sebaya, sedangkan self assessment merupakan penilaian yang dilakukan melalui analisis terhadap diri sendiri. Sejalan dengan pendapat Boud (dalam Astri 2016: 21) menjelaskan bahwa penilaian teman sejawat/ sebaya merupakan bentuk alternatif penilaian yang melibatkan peserta didik untuk memutuskan apakah nilai dari temanteman mereka telah memberikan kontribusi untuk proses pembelajaran.

Model penilaian afektif berbasis teknik peer and self assessment merupakan model penilaian inovatif yang sedang dikembangkan di dunia pendidikan karena model penilaian ini dapat memberikan dampak positif pada perkembangan kepribadian peserta didik (Muslich, 2014). Penilaian teman sejawat/ sebaya (peer assessment) bertujuan untuk menawarkan antara peserta didik dan memungkinkan peserta didik untuk membuat perbandingan satu sama lain. Penilaian diri sendiri (self assessment) 
bertujuan untuk mengembangkan keterampilan siswa dan kesadaran kritis yang memungkinkan peserta didik mampu untuk mengolah diri dan mengidentifikasi langkah selanjutnya dalam belajar dan untuk bergerak maju.

Manfaat lain dari teknik peer and self assessment yaitu peserta didik diberikan semangat/ termotivasi untuk belajar dan bersikap dengan baik, karena peserta didik terlibat langsung dalam penilaian sehingga peserta didik mampu mengetahu dan memahami aspek yang dinilai (Luca dan Mcloughlin, 2013). Kelebihan dan manfaat yang didapat dari penggunaan teknik peer and self assessment inilah menjadi dasar penilaian ini sebagai teknik yang dipilih untuk melakukan pengukuran sikap terhadap proses kegiatan pembelajaran.

Menurut Luca \& Mcloughlin (2013) dalam penelitiannya mencoba mengembangkan keterampilan dalam pendidikan. Keterampilan ini meliputi keterampilan tim, kemampuan memecahkan masalah, keterampilan pengambilan keputusan, kemampuan komunikasi, keterampilan literasi informasi, dan manajemen waktu. Pengembangan keterampilan tersebut, peserta didik harus terlibat dalam tugastugas yang akan membantu siswa merefleksikan kesuksesan mereka sendiri dalam menyelesaikan tugas. Literatur tentang belajar dan pengaturan diri dan mandiri. Penilaian sejawat adalah strategi penting yang digunakan untuk membantu mengembangkan keterampilan ini serta membantu untuk mempromosikan, mentransfer keterampilan untuk tempat kerja..

Muslich (2014) melakukan penelitian yang bertujuan untuk menghasilkan model penilaian afektif yang sesuai dengan kurikulum karena fakta dilapangan masih banyak guru yang belum melakukan penilaian sesuai dengan petunjuk penilaian efektif. Jenis penelitian ini adalah penelitian dan pengembangan, yaitu penelitian yang berusaha merancang dan menerapkan suatu model penilaian afektif dengan menggunakan spesifikasi tertentu sehingga dapat meningkatkan proses dan hasil pendidikan yang lebih baik. Muslich (2014) menerapkan teknik Peer dan Self Assessment untuk melakukan penilaian sikap. Teknik ini dipilih karena Peer dan Self Assessment memberikan beberapa keuntungan, diantaranya dapat menumbuhkan rasa percaya diri peserta didik, karena mereka diberi kepercayaan untuk mengevaluasi dan menilai dirinya sendiri, peserta didik menyadari kelebihan dan kelemahan dirinya, karena ketika mereka melakukan penilaian harus melakukan introspeksi terhadap kelebihan dan kelemahan yang dimilikinya dan dapat mendorong, membiasakan, dan melatih peserta didik untuk berbuat jujur, karena mereka dituntut untuk objektif dalam melakukan penilaian.

\section{SIMPULAN}

Kemampuan afektif merupakan bagian dari hasil belajar yang memiliki peran yang sangat penting. Keberhasilan pada ranah kognitif dan psikomotorik sangat ditentukan oleh kondisi afektif peserta didik. Peserta didik yang memiliki minat belajar dan sikap positif terhadap pelajaran akan merasa senang mempelajari mata pelajaran tertentu, sehingga dapat mencapai hasil pembelajaran yang optimal. Model penilaian afektif berbasis teknik peer and self assessment merupakan model penilaian inovatif yang sedang dikembangkan di dunia pendidikan karena model penilaian ini dapat memberikan dampak positif pada perkembangan kepribadian peserta didik.

\section{DAFTAR PUSTAKA}

Ardiana, M. \& Sudarmin, 2015. Penerapan Self Assessment untuk Analisis Keterampilan Berpikir Tingkat Tinggi Siswa. Jurnal Inovasi Pendidikan Kimia, IX (01): 1459-67. 
Astuti, W.P., P.A.P. \& Rahayu, E.S., 2012. Pengembangan Instrumen Asesmen Autentik Berbasis Literasi Sains pada Materi Sistem Ekskresi. Lembaran IImu Kependidikan, XLI.

Atina, Astri A'izzah. 2016. Pengembangan Instrumen Penilaian Afektif (Attittude Toward Chemistry) dengan Teknik Peer and Self Assessment Siswa SMA Negeri 2 Salatiga. Skripsi S1. Semarang: Universitas Negeri Semarang.

Basnet, B., 2011. Is Self-Assessment Effective In Enhancing Student Learning ? In AAEE Conference. Fremantle.

Basuki, Ismet. 2015. Asesmen Pembelajaran. Remaja Rosdakarya, Bandung.

Chaterine Anne S. Balanay. 2013. Assessment on Stunents' Science Process Skills: A Student- Centred, International Journal of Biology Education. Vol 5 No. 4 p. 162-171.

Cheung, D., 2011. Evaluating Student Attitudes toward Chemistry Lesson to Enhance Teaching In The Secondary School. Educacion Quimica, XXII(2): 117-22.

Dewi, N.L., Nyoman, D. \& Sadia, I.W., 2013. Pengaruh Model Pembelajaran Inkuiri Terbimbing Terhadap Sikap IImiah dan Hasil Belajar IPA. Jurusan Pendidikan Dasar, III.

Hamzah, Koni Satria. 2016. Asesmen Pembelajaran. Bumi Aksara, Jakarta.

Irsyad, M. \& Sukaesih, S., 2015. Pengembangan Asesmen Autentik Pada Materi Interaksi Makhluk Hidup dengan Lingkungan untuk Meningkatkan Kemampuan Berpikir Kritis Siswa. Unnes Science Education Journal, IV.

Kemendikbud. 2013. Permendikbud No 57 Tahun 2014 tentang Kurikulum SD/ MI. Kemendikbud: Jakarta.

Kemendikbud. (2016). Permendikbud Nomor 22 Tahun 2016 Tentang Standar Proses Pendidikan Dan Menengah. Jakarta: Kemendikbud.

Kusaeri, 2014. Acuan dan Teknik Penilaian Penilaian Proses dan hasil Belajar dalam Kurikulum 2013. Yogyakarta: AR-RUZZ MEDIA.

Luca, J. \& Mcloughlin, C., 2013. A Question of Balance : Using Self and Peer Assessment Effectively in Teamwork. Jurnal Of Education and Practice, IV.

Majid, A., 2014. Penilaian Autentik Proses dan Hasil Belajar. Bandung: PT Remaja Rosdakarya.

Muslich, M., 2014. Pengembangan Model Assessment Afektif Berbasis Self Assessment dan Peer Assessment di SMA Negeri 1 Kebonmas. Jurnal Kebijakan dan Pengembangan Pendidikan, II.

Muslikh.2016. Standar Isi Pendidikan Dasar Dan Menengah Direktur Jenderal Pendidikan Dasar, Jakarta.

Permendikbud Nomor 66 Tahun 2013 tentang Standar Penilaian Pendidikan.

Permendikbud Nomor 21 Tahun 2016 tentang Standar Isi Pendidikan Dasar dan Menengah.

Permendikbud Nomor 23 Tahun 2016 tentang Standar Penilaian Pendidikan.

Setiawan, Evelyn. 2016. Peer and Self Assessment in Accounting Education (Case Study of Accounting Education in UPH Surabaya). Journal of Accounting and Business Education, I (1), September 2016.

Subali, B. 2010. Buku Evaluasi Remediasi. FMIPA UNY. Yogyakarta.

Sukanti. 2011. Penilaian Afektif Dalam Pembelajaran Akuntansi. Jurnal Pendidikan Akuntansi Indonesia, 1, IX, hlm. $74-82$.

Wijayanti, A., 2014. Pengembangan Autentic Assessment Berbasis Proyek dengan Pendekatan Saintifik untuk Meningkatkan Keterampilan Berpikir Mahasiswa. 